AVRASYA Uluslararası Araştırmalar Dergisi Cilt:5 •Sayı:12•Özel Sayı 2017•Türkiye

\title{
А.К. КУШКУМБАЕВ. ГЕНЕАЛОГИЯ (ШЕЖИРЕ) КАРА-КЫПЧАКОВ КАК ИСТОРИЧЕСКИЙ ИСТОЧНИК (13 С.)
}

Prof. Dr. Valery STOJANOW*

В статье рассматривается вопрос об источниковой стоимости традиционных генеалогий - шежире («родословное дерево» - из арабского шаджаре «дерево», см. араб. шаджаре-ан-несаб, перс. шеджере-и на̄ме) тюркских конных народов. Первоначально сохранившиеся в устной традиции кочевникам приходилось вспоминать своих предков до семи «колен» (поколений) назад, с принятием ислама они стали фиксироваться в арабском письме, и в этом виде некоторые из них достигли до наших дней. Независимо от того, лежат ли корни этой традиции в эпохи Золотой Орды раннего средневековья или даже раньше - в так называемом «булгарском» периоде, она хорошо известна среди кыпчакских народов, образовавшихся на территории Золотой Орды. Европа встречается с ними через французский перевод работы Хивинского хана АбулГази Бахадура (1603-1663) «Шаджаре-и Тюрк» (впервые опубликованная в Лейдене в 1725 году), где, в духе библейской традиции, турки извлекаются из Яфиса (Иафета). Считается, что каждое отдельное племя имело собственное шаджаре - они использовались в качестве источников для последующих исторических обобщениях, например, в другой работе Абул-Гази, «Шаджаре-и Таракима» («Родословная туркмен», 1659). Но отдельные родня и семьи сохраняли тоже свои собственные шежире (короткие или пространные) - автор статьи упоминает выписки своего отца из родовой схемы, содержащей имена его предков.

В статье обращается внимание на значение «генеалогических структур (шежире)» степных племен, входящих в состав казахского народа. Эти «генеалогические нарративы», как называет их автор, содержат знания кочевников об их собственной истории, которые не менее важны, чем писания соседних народов. В казахской историографии этому историческому знанию устной традиции было присвоено обозначение «степная устная историология» или «устная история казахов» (своеобразная проекция метода Oral History, моя заметка, В.С.).

Автор прослеживает попыткам российских и казахских ученых собирать и анализировать традиционные шежире ещё с 18-19 века, выводя свои наблюдения до конца 20-го века. Он выделяет в четырех группах кыпчаков среди казахов и других тюркских народов, группа «кара-кыпчаков», которая была самым многочисленным, имела общая тамга (две вертикальные черты) и общий уран (боевой крик) - «Ойбас», по имени Ойбас-батыра, брат Токтар-бия, отец легендарного Кобыланды-батыра.

Далее автор ищет информацию об историческом Кобыланды, который жил бы во время золотоорденского хана Токтамыша (1380-1395) и, наверно, был сподвижником этого правителя. Он находит подтверждение для историчности

\footnotetext{
•Bulgaristan Bilimler Akademisi, Emekli-Profesör, valeryst@ihist.bas.bg
} 
Кобыланды-батыра в ногайско-золотоорденском эпическом материале. Сравнивая имена половецких кланов 11-го - начала 13-го века с более поздними, он обнаруживает, что едва ли существует преемственность до-монгольских и казахских кыпчаков. В использованная шежире кыпчаков из двадцатых годов 20 века автор прослеживает предков Кобыланды, в том числе и имя «Ақкөбік алып», которое он связывает с Кобяком (Карлыевичем) в русских хрониках. Обобщая сведения о Кобяка, в том числе информация Ан-Нувайри о враждебности сына Котяна из племени Дурут (срв. Дьорт-оба, Терт[е]р[о]бичи) с Аккубул/Ак-Кобяк из племени Токс-оба, автор приводит нас логически к связи/подчинение племя Токсобичи ордам Джучи. По его мнение, название Ак-Кибяк (Ак-Кобек) из арабских источников встречается «стабильно» в письменных материалов «раннеджукидского времени» и косвенно свидетельствует об историчности данных казахских шежире.

Работа ценна своим обобщениям и чрезвычайно полезна для изучения этнической (и генеалогической) истории Дешт-и Кипчака. Она также наводить на некоторые мысли, предлагая пути для их развития. Например, мы могли бы спросить, действительно ли русские фамильные (или отцовские) имена половецких ханов являются такие, или они иногда не отражают их тюркскую идентификацию (срв. aq-köpek «белая собака» и Кобяк Карлыевич в возможной этимологизации из Кобяк = köpek («собака») и Карлы = karlï («снежный»), т. е. «(Бело)снежная собака»? Позже имя его сына «Данило Кобякович», который был «более всех половцев», соответствует уже обычной русской именной номенклатуре.

Опираясь на актуальное значение этой проблематики для казахской историографии и на хорошо обоснованное изложение автора о связи шежиресведения с возможными историческими предками, я позволяю себя рекомендовать публикацию статьи профессора Айболата Кушкумбаева в «Avrasya Uluslararası Araştırmalar Dergisi / International Journal of Euroasian Researches». 